\title{
PENGARUH PRESTASI KERJA, SENIORITAS DAN LOYALITAS KARYAWAN TERHADAP PROMOSI JABATAN
}

\author{
Ni Made Okta Puspasari ${ }^{1}$ \\ I Gusti Bagus Honor Satrya ${ }^{2}$ \\ ${ }^{1,2}$ Fakultas Ekonomi dan Bisnis Universitas Udayana (Unud), Bali, Indonesia \\ email: nimadeoktapuspasari@yahoo.co.id
}

\begin{abstract}
ABSTRAK
Penelitian ini bertujuan untuk mengetahui pengaruh prestasi kerja, senioritas dan loyalitas karyawan terhadap promosi jabatan pada The Royal Pita Maha. Penelitian ini dilakukan di The Royal Pita Maha, dengan menggunakan teknik Proportionate Stratified Random Sampling, sebanyak 79 responden melalui metode rumus Slovin. Pengumpulan data melalui wawancara dan penyebaran kuesioner. Teknik analisis data yang digunakan adalah analisis regresi berganda, uji asumsi klasik, uji ketepatan model regresi, uji regresi parsial. Hasil dari penelitian ini menunjukkan bahwa prestasi kerja, senioritas dan loyalitas berpengaruh positif dan signifikan terhadap promosi jabatan. Implikasi pada penelitian ini adalah pihak manajemen The Royal Pita Maha perlu memperhatikan mengenai indikator-indikator dari prestasi kerja, senioritas dan loyalitas karyawan untuk menentukan promosi jabatan, sehingga karyawan merasa lebih adil dan lebih termotivasi dalam bekerja untuk mendapatkan jabatan yang lebih tinggi.
\end{abstract}

Kata kunci : prestasi kerja, senioritas, loyalitas, promosi jabatan

\section{ABSTRACT}

This study aims to determine the effect of work performance, seniority and employee loyalty on job promotion at The Royal Pita Maha. This research was conducted at The Royal Pita Maha, using the Proportionate Stratified Random Sampling technique, as many as 79 respondents through the Slovin formula method. Data collection through interviews and questionnaires. The data analysis technique used is multiple regression analysis, classic assumption test, accuracy test regression model, partial regression test. The results of this study indicate that work performance, seniority and loyalty have a positive and significant effect on promotion. The implication in this study is that the management of The Royal Pita Maha needs to pay attention to the indicators of work performance, seniority and employee loyalty to determine promotion, so that employees feel more just and more motivated to work to get higher positions.

Keywords: work performance, seniority, loyalty, promotion 


\section{PENDAHULUAN}

Peningkatan jumlah kedatangan wisatawan ke Bali selalu terjadi setiap tahunnya. Peningkatan tersebut diikuti dengan pertumbuhan jumlah hotel yang begitu pesat. Semakin banyaknya jumlah hotel yang berdiri di Bali membuat persaingan bisnis jasa perhotelan semakin sengit. Tentu saja situasi ini membuat perusahaan untuk memiliki sumber daya manusia (SDM) yang berkualitas dalam memberikan pelayanan yang profesional kepada konsumen. Ardana dkk. (2012:3) menyatakan bahwa sumber daya manusia (SDM) adalah harta atau aset paling berharga yang dimiliki oleh satu organisasi atau perusahaan, karena keberhasilan organisasi sangat ditentukan oleh unsur manusia.

Persaingan antar perusahaan di era globalisasi semakin tajam, sehingga perusahaan dituntut untuk terus-menerus mengembangkan SDM yang dimiliki secara proaktif, sehingga potensi mereka berkembang secara maksimal. Organisasi harus memiliki pemimpin yang mampu memimpin dan memotivasi karyawan untuk mencapai tujuan organisasi, karena pemimpin yang baik selalu dapat menginspirasi karyawan untuk menjadi lebih baik (Chen et al., 2016)

Promosi jabatan memainkan peran penting, dimana dengan adanya promosi jabatan, karyawan akan merasa dihargai, termotivasi dalam bekerja, dibutuhkan, diperhatikan, dan diakui kemampuan kerjanya, sehingga mereka akan menghasilkan output yang tinggi (Cressida dkk., 2013). Promosi adalah salah satu dari beberapa jenis pengembangan karier, mendapatkan promosi adalah impian atau tujuan seorang karyawan yang memiliki prestasi kerja yang baik (Rinaldi dkk., 2018)

Hasil penelitian yang dilakukan oleh Dasplin (2014) bahwa promosi memberikan efek positif yang signifikan terhadap pengembangan karir karyawan, yang akan menghasilkan hal-hal positif bagi karyawan yaitu meningkatkan pengetahuan dan pengalaman mereka. Menurut Saharuddin \& Sulaiman (2016) promosi mampu mendorong karyawan untuk bekerja lebih keras dan ini perlu dipertahankan untuk terus meningkatkan semangat kerja karyawan. Promosi diberikan untuk memotivasi semangat kerja karyawan, karyawan yang dipromosikan akan memiliki tanggung jawab yang lebih besar, martabat atau status yang lebih tinggi, dan diharapkan memiliki keterampilan yang lebih baik (Rinaldi dkk., 2018)

Keputusan promosi jabatan tidak hanya penting untuk karier karyawan, namun juga untuk meningkatkan kepuasan kerja (Busswolder et al., 2019). Para pemimpin harus menyadari pentingnya promosi dalam meningkatkan kinerja karyawan harus dipertimbangkan secara objektif (Sarboni, 2016) . Jika pemimpin sudah sadar untuk mempertimbangkan promosi secara objektif, maka perusahaan akan terhindar dari masalah yang menunda peningkatan output dan itu bisa merugikan perusahaan seperti: ketidakpuasan karyawan, keluhan, kurangnya semangat kerja, menurunnya disiplin kerja, dan banyak dari mereka absen atau bahkan masalah mogok kerja (Sarboni, 2016).

Promosi akan dilaksanakan dan bertujuan untuk mengembangkan, memajukan pegawai dan meningkatkan tanggung jawab yang lebih besar kepada pegawai, dimana dengan adanya pemberian promosi akan dapat mempertinggi semangat dan kegairahan kerja pegawai, serta dapat menjamin stabilitas pegawai 
yaitu dengan adanya promosi akan mengurangi permintaan untuk pindah kerja (Sinaga, 2014). Dengan demikian proses pekerjaan dalam suatu instansi dapat berjalan dengan lancar (Sinaga, 2014).

Menurut Busari et al. (2017)promosi jabatan adalah ketika seseorang bergerak dari satu posisi ke posisi yang lebih tinggi dengan tanggung jawab yang lebih besar. Pendapat serupa juga disampaikan oleh Siagian (2014:170), bahwa promosi jabatan didefinisikan sebagai perpindahan pegawai dari satu pekerjaan ke pekerjaan lain yang tanggung jawabnya lebih besar, tingkat hirarki jabatannya lebih tinggi dan penghasilannya pun lebih besar pula.

Pedoman yang dijadikan dasar untuk mempromosikan karyawan menurut Hasibuan (2013:109) meliputi: pengalaman atau orang yang telah lama bekerja dalam perusahaan, kecakapan, atau kombinasi dari pengalaman dan kecakapan. Kreteria utama dalam mempertimbangkan seseorang untuk dipromosikan, yaitu prestasi kerja, senioritas, dan loyalitas (Siagian, 2014:170; Hasibuan, 2013:111).

Faktor yang perlu diperhatikan terkait apakah karyawan sebuah perusahaan layak untuk mendapatkan promosi jabatan atau tidak adalah dengan melihat prestasi dari karyawan tersebut (Sasmita \& Mujiati, 2016). Perusahaan saat ini tidak sembarangan dalam memilih dan menempatkan karyawannya dalam suatu posisi jabatan. Menurut Mangkunegara (2011:67) prestasi kerja adalah hasil kerja secara kualitas dan kuantitas yang dicapai oleh seseorang karyawan dalam melaksanakan tugasnya sesuai dengan tanggungjawab yang diberikan kepadanya.

Pendapat lain dari Prabowo dkk. (2016) prestasi kerja adalah hasil kerja atau pencapaian dari seorang karyawan atas kewajibannya dalam melaksanakan pekerjaan yang dapat diukur dari segi kuantitas, kualitas dan ketepatan waktu.. Penilaian prestasi kerja tersebut meliputi kualitas pekerjaan, kuantitas pekerjaan, ketepatan waktu, dan kerjasama dengan rekan kerja (Siska \& Suryalena, 2017)

Karyawan dapat dikatakan memiliki prestasi kerja yang baik apabila dapat memberikan hasil terbaik untuk pekerjaannya artinya karyawan tersebut dapat mencapai atau melebihi standar atau kriteria tertentu yang di tetapkan organisasi. Penilaian prestasi kerja ini juga akan berpengaruh terhadap kinerja organisasi tersebut. Karyawan tersebut bisa mengembangkan karir mereka menjadi lebih tinggi dan ini akan berdampak positif bagi organisasi dimana karyawan tersebut berada. Menurut Roswaty \& Kurniawan (2016) penghargaan atas hasil berupa prestasi kerja biasanya dinyatakan dalam bentuk promosi jabatan. Promosi jabatan bagi manajer diberikan kepada karyawan sebagai reward atas kinerja yang dilakukan oleh karyawan bagi perusahaan.

Di sisi lain tingkat senioritas karyawan juga dapat menentukan promosi jabatan, karyawan yang masa kerjanya paling lama adalah karyawan yang paling berhak untuk dipromosikan jabatannya (Breaugh, 2011). Senioritas secara harfiah diartikan sebagai keadaan yang lebih tinggi dalam hal pangkat, usia dan pengalaman. Pendapat lain dari Nitisemito (2008:149) mengemukakan bahwa senioritas sebagai lamanya masa kerja seseorang yang diakui prestasinya baik pada jabatan yang bersangkutan ataupun dalam instansi keseluruhan.

Dalam senioritas tercermin pula pengertian usia serta pengalaman kerja seseorang. Senioritas dapat dilihat dari beberapa aspek, diantaranya yaitu usia, masa kerja dan pengalaman (Purwaningsih \& Magdalena, 2017). Seorang karyawan yang 
telah cukup lama bekerja di perusahaan biasanya akan mempunyai kemampuan yang lebih dan memiliki pengalaman yang lebih banyak meskipun berada di satu jabatan yang sama (Purwaningsih \& Magdalena, 2017).

Penelitian yang dilakukan oleh Barusman \& Siswadi (2018) mengatakan bahwa pengalaman adalah faktor yang paling dominan dalam mempengaruhi seleksi pada promosi jabatan. Menurut Razak et al. (2018) senioritas adalah dasar dari promosi terbaik dan paling tepat karena mempromosikan orang yang paling berpengalaman dari keterampilan yang baik adalah cara yang paling efektif untuk mempromosikan jabatan. Penelitian Carter (2017) mengatakan bahwa dalam sistem promosi berbasis senioritas, karyawan menganggap sistem promosi mereka lebih adil dari pada sistem berbasis prestasi.

Selain itu, dalam melaksanakan promosi jabatan hal yang juga harus dilihat adalah sejauh mana loyalitas karyawan terhadap perusahaan. Karyawan yang loyal dapat menjadi aset yang sangat berharga bagi perusahaan (Sihombing \& Berlianto, 2017). Cerminan loyalitas karyawan dapat dilihat dari seberapa besar karyawan merasa nyaman di perusahaan (Sari \& Daulay, 2015). Secara umum loyalitas dapat diartikan dengan kesetiaan, pengabdian dan kepercayaan yang diberikan atau ditujukan kepada seseorang atau lembaga, yang di dalamnya terdapat rasa cinta dan tanggung jawab untuk berusaha memberikan pelayanan dan perilaku terbaik (Rasimin, 2008:49).

Loyalitas kerja merupakan salah satu faktor yang mempengaruhi promosi jabatan, karena karyawan yang memiliki loyalitas kerja tinggi dianggap mampu memberikan hasil yang maksimal dalam pencapaian tujuan perusahaan (Hamzah dkk., 2013). Oleh karena itu loyalitas dalam perusahaan sangat diperlukan karena sangat mempengaruhi kesuksesan dari perusahaan (Desmita \& Kasmiruddin, 2018). Loyalitas kerja merupakan kesetiaan karyawan terhadap perusahaan yang akan menimbulkan rasa tanggung jawab, sehingga karyawan akan tetap bertahan dalam perusahaan tersebut walaupun perusahaan dalam keadaan maju atau mundur (Stephani \& Wibawa, 2014)

Menurut Onsardi (2016) mengatakan bahwa seorang karyawan setia kepada organisasinya ketika dia menunjukkan komitmen dan keyakinan bahwa bekerja di organisasi adalah pilihan terbaik baginya. Untuk itu karyawan akan mencoba yang terbaik untuk kesuksesan perusahaan agar tetap terus bertahan (Adedeji \& Ugwumadu, 2018). Pendapat yang sama di sebutkan oleh Waqas et al. (2014) karyawan yang loyal adalah orang yang memiliki komitmen tinggi untuk mengembangkan organisasi.

Tomic et al. (2018) mengatakan bahwa, jika karyawan berkomitmen kepada organisasi dan berkinerja di jabatan yang sesuai ,ini akan memiliki dampak positif pada kinerja organisasi. Menurut George et al. (2016) loyalitas karyawan diukur dari sikap kerja, etika kerja dan kemauan untuk bertahan dalam jangka panjang di perusahaan.

Pemaparan diatas menunjukan bahwa variabel prestasi kerja, senioritas dan loyalitas berpengruh terhadap sistem promosi. Pra-riset yang muncul terkait dengan sistem promosi jabatan pada The Royal Pita Maha, menurut hasil wawancara 12 orang karyawan, permasalahan terletak pada Promosi jabatan hanya berdasarkan prestasi kerja, dimana karyawan yang sudah senior dan loyal pada perusahaan 
belum tentu dapat di promosikan, hal ini mengakibatkan hilangnya senioritas dan loyalitas karyawan pada perusahaan yang pada akhirnya mempengaruhi sistem promosi jabatan.

Karyawan yang takut untuk dipromosikan karena akan mengambil tanggung jawab yang lebih besar yang akan dibebankannya nanti, karena karyawan tersebut merasa tidak memiliki kemampuan kepemimpinan sebuah tim, padahal karyawan tersebut memiliki potensi untuk dipromosikan yaitu berprestasi dalam berkerja dan loyal pada perusahaan, tentu saja hal ini akan memperhambat jalannya sistem promosi jabatan.

Promosi jabatan dilihat dari sisi kecakapan dari karyawan tersebut tanpa melihat latar belakang pendidikan dan pemimpinan cenderung melakukan penilaian pada faktor kedekatan, lebih memprioritaskan yang pertama adalah pegawai asli Ubud dan yang kedua adalah pegawai asli Bali. Hal ini akan mengakibatkan adanya ketidak adilan dalam mempromosikan karyawan.

Ketika individu merasa tidak adanya keadilan dalam perusahaan, semangat mereka pasti akan menurun, mereka menjadi lebih memungkinkan untuk meninggalkan pekerjaan mereka, dan bahkan mungkin mereka akan melakukan perlawanan terhadap perusahaan. Jika atasan dapat mempromosikan karyawan dengan sistem yang baik serta mempromosikan mereka ke posisi yang sesuai, itu akan meningkatkan semangat kerja karyawan dan karyawan akan memiliki keyakinan dan percaya pada perusahaan yang sudah mengenali kerja keras dan kinerja mereka (Harmania \& Nessa, 2017). Oleh karena pentingnya setiap perusahaan untuk memiliki sistem promosi yang baik, khususnya pada industri hotel di Bali, maka masih diperlukan penelitian lanjutan yang terfokus pada pengembangan sistem promosi jabatan yang baik dan adil bagi karyawan.

Manajer Human Resources Departement (HRD) 2018 mengatakan bahwa promosi jabatan pada The Royal Pita Maha mengutamakan orang dalam untuk di promosikan. Sebagian besar perusahaan telah menetapkan prosedur promosi dengan lebih memilih promosi dari dalam perusahaan dari pada merekrut dari luar (Kwon \& Meyersson Milgrom, 2014). Pendapat yang sama di sebutkan oleh Matias \& Bentor (2016) lebih memprioritaskan orang dalam yang di promosikan untuk menghindari masalah adanya pilih kasih yang akan dirasakan karyawan. Kriteria karyawan yang akan dipromosikan adalah profesionalisme dalam bekerja, integritas, dan bertanggung jawab, namun kreteria yang paling diutamakan adalah karyawan yang memiliki sikap, kemampuan dan pengetahuan.

Penilaian dalam mempromosikan karyawan pada The Royal Pita Maha yang pertama karyawan akan di rekomendasikan oleh supervisor, selanjutnya akan di nilai melalui metode penilaian dengan sistem $360^{\circ}$ dan metode check list. Penilaian dengan sistem $360^{\circ}$ maksudnya adalah penilaian satu karyawan dilakukan oleh atasan, rekan kerja yang sejajar / setingkat, dan bawahannya (Suswanto, 2016) dan yang dimaksudkan penilaian dengan metode check list adalah menilai dengan formulir penilaian. Setelah dinilai, formulir penilaian tersebut akan diserahkan kepada HRD dan diserahkan ke Resort Manager dan General Manager. Setelah disetujui maka karyawan yang terpilih akan di tetapkan pada jabatan yang lebih tinggi. 
Penelitian ini dilakukan di The Royal Pita Maha yang terletak di Kedewatan, Ubud, Gianyar, Bali. The Royal Pita Maha adalah hotel bintang lima. Alasan penelitian memilih konteks di Hotel ini adalah karena The Royal Pita Maha selalu membuka peluang untuk karyawannya dipromosikan ke tingkat jabatan yang lebih tinggi. Jadi tidak menutup kemungkinan bagi karyawan tetap untuk dipromosikan ke jabatan yang lebih baik.

Oleh karena pentingnya setiap perusahaan untuk memiliki sistem promosi yang baik, khususnya pada industri hotel di Bali, maka masih diperlukan penelitian lanjutan yang terfokus pada pengembangan sistem promosi yang baik dan adil bagi karyawan. Berdasarkan permasalahan tersebut, tujuan dari penelitian ini adalah untuk mengetahui pengaruh prestasi kerja, senioritas, dan loyalitas terhadap promosi jabatan pada The Royal Pita Maha.

Promosi Jabatan adalah perpidahan yang memperbesar authority dan responsibility karyawan ke jabatan yang lebih tinggi di dalam suatu organisasi sehingga kewajiban, hak, status dan penghasilannnya semakin besar (Hasibuan, 2013:109). Promosi merupakan hal yang sangat diperlukan dalam sebuah organisasi. Kesempatan bagi setiap karyawan untuk dipromosikan berdasarkan atas keadilan dan objektivitas, karyawan akan terdorong untuk berkerja lebih giat, bersemangat, berdisiplin, dan berprestasi kerja, sehingga sasaran perusahaan secara optimal dapat dicapai (Hasibuan, 2013:109)

Berdasarkan penelitiannya, Cressida dkk. (2013) mendapatkan hasil bahwa prestasi kerja berpengaruh terhadap promosi jabatan dilihat dari kualitas hasil kerja, kuantitas hasil kerja, dan ketepatan waktu penyelesaian hasil kerja. Penelitian Ismawan (2006) mendapatkan hasil bahwa terdapat hubungan positif antara prestasi kerja dengan promosi jabatan, dimana semakin berprestasi karyawan semakin besar peluangnya untuk dipromosikan.

$\mathrm{H}_{1}$ : Prestasi kerja berpengaruh positif terhadap promosi jabatan.

Penelitian Mirayanti (2015) mengatakan bahwa loyalitas secara parsial berpengaruh positif dan signifikan terhadap romosi jabatan, begitu pula dengan penelitian Hamzah dkk. (2013) menunjukkan bahwa senioritas berpengaruh signifikan terhadap promosi jabatan, hal ini menunjukkan bahwa sistem senioritas pada dasarnya merupakan suatu bentuk penghargaan organisasi kepada tenaga kerja atas kesetiaan dan dedikasinya kepada organisasi.

Senioritas yang ada diperusahaan masih berpengaruh kuat dalam penentuan promosi jabatan meskipun tidak menjadi satu-satunya syarat utama dalam penentuan promosi jabatan (Purwaningsih \& Magdalena, 2017). Senioritas masih memainkan peran dominan dalam keputusan promosi (Horak \& Yang, 2017). peran spesifik dari senioritas sangat menentukan keputusan promosi jabatan, di mana senioritas juga dapat membantu manajerial untuk adil dalam promosi jabatan dan melindungi terhadap tantangan diskriminasi.

$\mathrm{H}_{2}$ : Senioritas berpengaruh positif terhadap promosi jabatan.

Loyalitas adalah suatu sikap mental karyawan yang ditujukan kepada keberadaan perusahaan sehingga karyawan akan tetap bertahan dalam perusahaan, tanpa mempedulikan kondisi perusahaan saat itu (Ardana dkk., 2012:136). Penelitian dari Arifin \& Mutamimah (2009) mendapatkan hasil bahwa motivasi yang diberikan pimpinan akan berpengaruh terhadap loyalitas karyawan, dimana 
tingkat loyalitas karyawan yang tinggi akan berpengaruh terhadap promosi jabatan. Loyalitas memiliki pengaruh dan signifikan terhadap promosi jabatan (Pratimi \& Utama, 2016). Hasil dari penelitian Ningsih (2013) menyebutkan bahwa loyalitas memiliki nilai persentase tertinggi, dengan demikian secara keseluruhan karyawan yang memiliki loyalitas tinggi terhadap perusahaan akan memiliki kesempatan lebih besar untuk mendapatkan promosi jabatan.

$\mathrm{H}_{3}$ : Loyalitas berpengaruh positif terhadap promosi jabatan.

\section{METODE PENELITIAN}

Berdasarkan permasalahan yang diteliti, penelitian ini digolongkan pada penelitian asosiatif kausal, yaitu suatu penelitian yang bersifat menanyakan hubungan antara dua variabel atau lebih. Penelitian ini bertujuan untuk meneliti dan menjelaskan pengaruh prestasi kerja, senioritas dan loyalitas terhadap promosi jabatan

Penelitian ini dilakukan di The Royal Pita Maha yang terletak di Jalan Kedewatan, Ubud, Gianyar, Bali, Indonesia. Perusahaan ini bergerak di dalam bidang perhotelan. The Royal Pita Maha terletak pada lereng perbukitan lembah sungai Ayung, yang terkenal dengan pemandangan sungai dan suasana alamnya yang indah. The Royal Pita Maha dapat dicapai dengan berkendaraan selama sekitar 1 jam dari bandara internasional Ngurah Rai Bali.

Subjek penelitian yang digunakan dalam penelitian kali ini adalah seluruh karyawan The Royal Pita Maha tidak termasuk daily worker, manajer dan pemilik. Adapun obyek dalam penelitian ini adalah mengenai prestasi kerja, senioritas, loyalitas dan promosi jabatan karyawan pada The Royal Pita Maha.Dalam penelitian ini yang merupakan variabel terikatnya adalah Promosi Jabatan (Y). Dalam penelitian ini yang merupakan variabel bebasnya adalah Prestasi Kerja $\left(\mathrm{X}_{1}\right)$, Senioritas $\left(\mathrm{X}_{2}\right)$, dan Loyalitas $\left(\mathrm{X}_{3}\right)$.

Populasi dalam penelitian ini adalah seluruh karyawan The Royal Pita Maha yang berjumlah 366 karyawan tidak termasuk daily worker, manajer dan owner. Teknik pengambilan sampel dalam penelitian ini menggunakan teknik Proportionate Stratified Random Sampling, teknik ini digunakan bila populasi mempunyai anggota/unsur yang tidak homogen dan berstrata secara proporsional. Metode penentuan sampel yang diambil dalam penelitian ini menggunakan rumus Slovin. Penggunaan rumus slovin karena peneliti hanya membutuhkan sampel untuk mewakili dari seluruh populasi, adapun rumus slovin yaitu sebagai berikut:

$\mathrm{n}=\frac{N}{1+N e^{2}}=\frac{366}{1+366 \times 0,10^{2}}=78,54$

Keterangan:

$\mathrm{n}=$ sampel

$\mathrm{N}=$ populasi

$\mathrm{e}=$ error. Pada penelitian ini error ditetapkan $10 \%$

Dari perhitungan di atas, maka sampel yang digunakan berjumlah 78,54 yang kemudian dibulatkan menjadi 79 responden. Jadi sampelyang gunakan berjumlah 
79 karyawan tidak termasuk owner, manajer dan daily walker. Owner tidak mengikuti promosi jabatan karena owner adalah pemilik perusahaan yang jabatannya paling tinggi dalam perusahaan. Manajer tidak dapat mengikuti promosi jabatan karena posisi tersebut adalah tingkatan paling akhir dalam promosi jabatan. Daily walker juga tidak dapat dikatakan promosi jabatan karena daily walker adalah pegawai kontrak, dimana pegawai kontrak yang akan di jadikan pegawai tetap hanya akan mengubah status dari pegawai kontrak menjadi pegawai tetap.

Metode pengumpulan data yang digunakan dalam penelitian ini adalah dengan wawancara dan kuesioner. Kuesioner yaitu metode pengumpulan data yang dilakukan dengan cara memberi seperangkat pertanyaan atau pernyataan tertulis kepada 79 responden untuk dijawab. Kuesioner diberikan kepada responden penelitian yang memiliki kriteria sudah ditentukan. Pengukuran data dalam penelitian ini untuk variabel promosi jabatan, loyalitas dan promosi jabatan menggunakan skala Likert. Wawancara dilakukan dengan melakukan tanya jawab secara langsung terhadap pihak-pihak yang berkompeten terhadap penelitian ini yaitu HRD (2018) dan seorang Departement Head The Royal Pita Maha. Data yang diperoleh dalam penelitian ini adalah sejarah singkat perusahaan, gambaran umum perusahaan, dan struktur organisasi serta wawancara singkat tentang permasalahan terkait dengan promosi jabatan, prestasi kerja, senioritas dan loyalitas karyawan pada The Royal Pita Maha.

Data Kuantitatif dari penelitian ini adalah jumlah karyawan pada The Royal Pita Maha serta jumlah skor jawaban kuisioner yang telah dikuantitatifkan dengan pembobotan jawaban responden.Data kualitatif dalam penelitian ini seperti struktur organisasi, gambaran umum dan sejarah singkat The Royal Pita Maha. Data primer dalam penelitian ini diperoleh dengan memberikan kuesioner yang meliputi tentang prestasi kerja, senioritas, loyalitas, dan promosi jabatan yang diberikan kepada 79 karyawan The Royal Pita Maha yang bertindak sebagai sampel. Sumber data sekunder adalah sumber data yang tidak langsung memberikan data kepada pengumpul data, misalnya lewat orang lain atau lewat dokumen. Sumber data sekunder dalam penelitian ini adalah buku-buku, jurnal-jurnal penelitian terdahulu, gambaran umum dan data jumlah karyawan dari pihak perusahaan The Royal Pita Maha 2018.

Model analisis yang dipergunakan untuk menyelesaikan permasalahan dalam penelitian ini adalah regresi linier berganda. Analisis ini digunakan untuk mengetahui ketergantungan suatu variabel terikat dengan satu atau lebih variabel bebas. Analisis ini juga dapat menduga besar dan arah hubungan tersebut serta mengukur derajat keeratan antara satu variabel terikat dengan satu atau lebih variabel bebas. Dalam analisis ini, penelitian akan dibantu dengan program komputer yaitu SPSS.

$\dot{Y}=a+b_{1} X_{1}+b_{2} X_{2}+b_{3} X_{3}+e$

Keterangan:

$\begin{array}{ll}\mathrm{X}_{1} & =\text { Pemberdayaan } \\ \mathrm{X}_{2} & =\text { Perilaku Inovatif } \\ \mathrm{X}_{3} & =\text { Motivasi Kerja }\end{array}$




$$
\begin{array}{ll}
\mathrm{Y} & =\text { Produktivitas Kerja } \\
\mathrm{b}_{1} \mathrm{~b}_{2} \mathrm{~b}_{3} & =\text { Koefisien regresi } \mathrm{X}_{1} \mathrm{X}_{2} \mathrm{X}_{3} \\
\mathrm{e}_{\mathrm{i}} & =\text { Error }
\end{array}
$$

\section{HASIL DAN PEMBAHASAN}

Karakteristik responden merupakan data responden yang dikumpulkan untuk mengetahui profil responden penelitian. Dari hasil penelitian yang dilakukan terhadap karyawan The Royal Pita Maha, dapat diketahui gambaran tentang karakteristik responden yang meliputi tiga aspek yaitu jenis kelamin, usia dan total masa kerja keseluruhan didalam perusahaan.

Tabel 1.

Karakteristik Responden Karyawan di The Royal Pita Maha

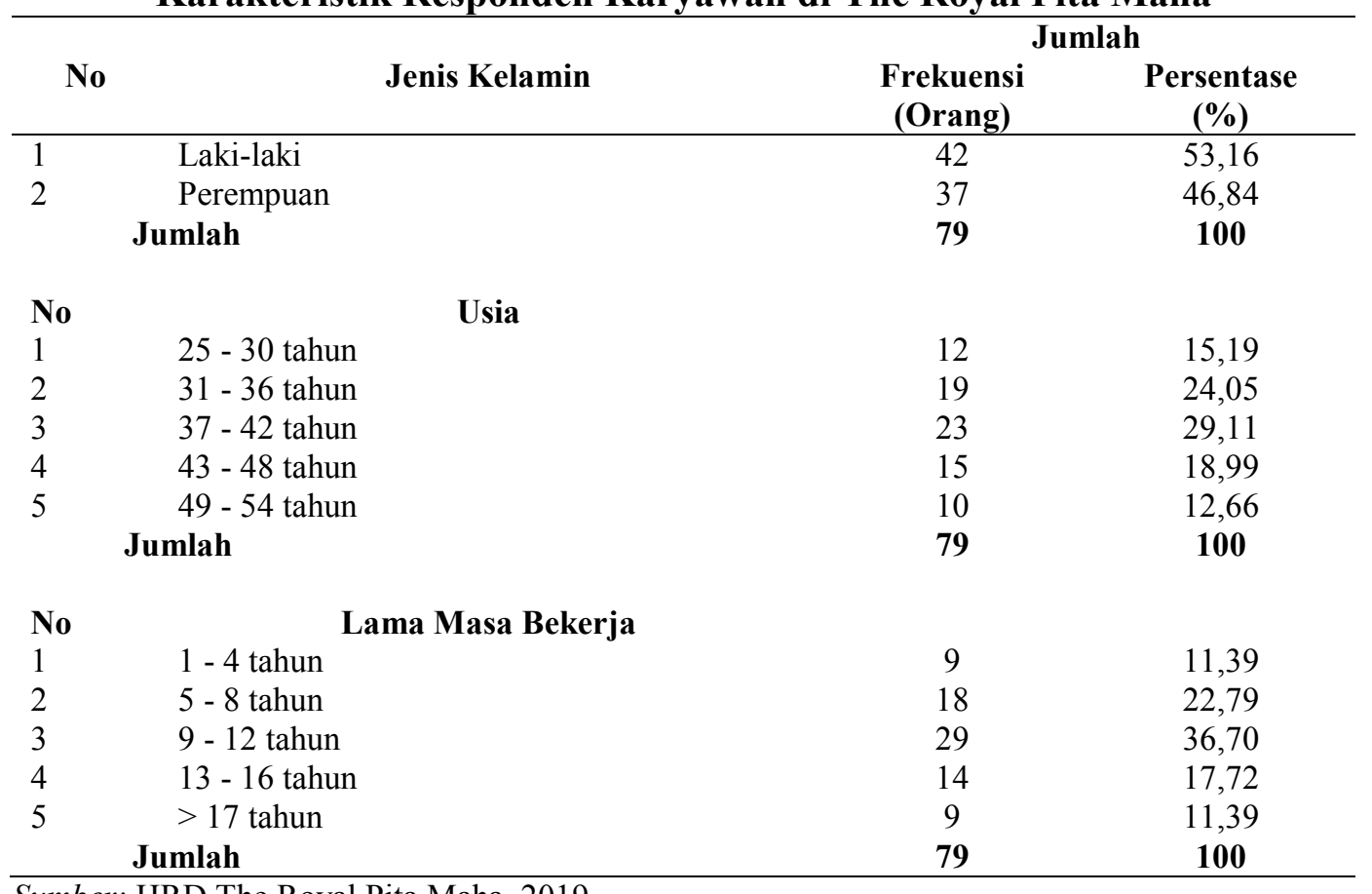

Sumber: HRD The Royal Pita Maha, 2019

Tabel 1. menunjukkan bahwa jumlah responden sebanyak 79 orang dengan persentase laki-laki sebesar 53,16 persen sedangkan perempuan sebesar 46,84 persen. Hal ini berarti sebagian karyawan The Royal Pita Maha di dominasi oleh laki-laki, karena industri perhotelan, dimana lebih banyak mengandalkan House Keeping, Bellboy dan Kitchen Chief . Ketiga departemen tersebut memerlukan banyak tenaga laki-laki. Dari segi umur menunjukkan bahwa sebagian besar responden berumur 37 - 42 tahun dengan persentase yaitu 29,11 persen. Persentase terkecil yaitu 12,66 persen dengan jumlah responden sebanyak 10 orang yang berumur 49 - 54 tahun.

Hal ini berarti bahwa, karyawan The Royal Pita Maha rata-rata berumur 37 42 tahun di mana pada umur ini seorang tenaga kerja dapat dikatakan produktif dan kreatif dalam bekerja. Dari masa kerja menunjukkan bahwa sebagian besar 
responden memiliki masa kerja 9 - 12 tahun sebesar 36,70 persen, sedangkan responden dengan persentase terkecil memiliki masa kerja $1-4$ tahun yaitu sebesar 11,39 persen dan $>17$ tahun yaitu sebesar 11,39 persen. Ini menyatakan bahwa karyawan pada The Royal Pita Maha cukup berpengalaman apabila dilihat dari masa kerja.

Tabel 2.

Rekapitulasi Hasil Uji Validitas Instrumen Penelitian

\begin{tabular}{ccccc}
\hline Variabel & Indikator & Koefisien Korelasi & Sig. (2-tailed) & Keterangan \\
\hline & $\mathrm{X}_{1.1}$ & 0,629 & 0,000 & Valid \\
& $\mathrm{X}_{1.2}$ & 0,657 & 0,000 & Valid \\
& $\mathrm{X}_{1.3}$ & 0,669 & 0,000 & Valid \\
Prestasi kerja $\left(\mathrm{X}_{1}\right)$ & $\mathrm{X}_{1.4}$ & 0,688 & 0,000 & Valid \\
& $\mathrm{X}_{1.5}$ & 0,707 & 0,000 & Valid \\
& $\mathrm{X}_{1.5}$ & 0,758 & 0,000 & Valid \\
& $\mathrm{X}_{1.5}$ & 0,612 & 0,000 & Valid \\
& $\mathrm{X}_{1.5}$ & 0,634 & 0,000 & Valid \\
& $\mathrm{X}_{1.5}$ & 0,750 & 0,000 & Valid \\
& $\mathrm{X}_{1.5}$ & 0,546 & 0,002 & Valid \\
& $\mathrm{X}_{3.1}$ & 0,817 & 0,000 & Valid \\
Loyalitas $\left(\mathrm{X}_{3}\right)$ & $\mathrm{X}_{3.2}$ & 0,817 & 0,000 & Valid \\
& $\mathrm{X}_{3.3}$ & 0,847 & 0,000 & Valid \\
& $\mathrm{X}_{3.4}$ & 0,688 & 0,000 & Valid \\
& $\mathrm{X}_{3.5}$ & 0,736 & 0,000 & Valid \\
& $\mathrm{Y}_{1}$ & 0,801 & 0,000 & Valid \\
& $\mathrm{Y}_{2}$ & 0,667 & 0,000 & Valid \\
& $\mathrm{Y}_{3}$ & 0,870 & 0,000 & Valid \\
& $\mathrm{Y}_{4}$ & 0,809 & 0,000 & Valid \\
& $\mathrm{Y}_{5}$ & 0,871 & 0,000 & Valid \\
\hline Promosi Jabtan & $\mathrm{Y}_{6}$ & 0,766 & 0,000 & Valid \\
\hline
\end{tabular}

Sumber: Data diolah, 2019

Suatu instrumen dalam penelitian dikatakan valid apabila mampu mengukur apa yang ingin diukur. Suatu instrumen dikatakan valid apabila memiliki koefisien korelasi antara butir dengan skor total dalam instrumen tersebut lebih besar dari 0,30 dengan tingkat kesalahan Alpha 0,05. Tabel 2. berikut menyajikan hasil uji validitas instrumen penelitian.

Hasil uji validitas pada Tabel 2. menunjukkan bahwa seluruh instrumen penelitian yang digunakan untuk mengukur variabel prestasi kerja, senioritas, loyalitas dan promosi jabatan memiliki nilai koefisien korelasi dengan skor total seluruh item pernyataan lebih besar dari 0,30 dengan signifikansi kurang dari 0,05. Hal ini menunjukkan bahwa butir-butir pernyataan dalam instrument penelitian tersebut valid dan layak digunakan sebagai instrument penelitian

Uji Reliabilitas terhadap instrumen penelitian ini menggunakan nilai Cronbach's Alpha yakni untuk mengetahui unidimensionalitas butir-butir pernyataan terhadap variabel laten yang diteliti (prestasi kerja, senioritas, loyalitas dan promosi jabatan). Nilai Cronbach's Alpha dinyatakan reliabel jika nilainya lebih besar atau sama dengan 0,60. Rekapitulasi hasil uji reliabilitas instrumen penelitian dapat dilihat pada Tabel 3 berikut. 
Tabel 3.

Rekapitulasi Hasil Uji Reliabilitas Instrumen Penelitian

\begin{tabular}{clcc}
\hline No. & \multicolumn{1}{c}{ Variabel } & Cronbach's Alpha & Keterangan \\
\hline $\mathbf{1}$ & Prestasi kerja $\left(\mathrm{X}_{1}\right)$ & 0,763 & Reliabel \\
$\mathbf{2}$ & Loyalitas $\left(\mathrm{X}_{3}\right)$ & 0,802 & Reliabel \\
$\mathbf{3}$ & Promosi jabatan $(\mathrm{Y})$ & 0,798 & Reliabel \\
\hline Sumber: & Data diolah, 2019 & &
\end{tabular}

Sumber: Data diolah, 2019

Hasil uji reliabilitas yang disajikan dalam Tabel 3. menunjukkan bahwa seluruh instrumen penelitian memiliki koefisien Cronbach's Alpha lebih dari 0,60. Jadi dapat dinyatakan bahwa seluruh variabel telah memenuhi syarat reliabilitas atau kehandalan sehingga dapat digunakan untuk melakukan penelitian.

Perhitungan koefisien regresi linier berganda dilakukan dengan analisis regresi melalui software SPSS 18.0 for Windows, diperoleh hasil yang ditunjukan pada Tabel 4.

Tabel 4.

Hasil Analisis Regresi Linier Berganda

\begin{tabular}{|c|c|c|c|c|c|}
\hline \multirow[t]{2}{*}{ Variabel } & \multicolumn{2}{|c|}{$\begin{array}{c}\text { Unstandardized } \\
\text { Coefficients }\end{array}$} & \multirow{2}{*}{$\begin{array}{c}\text { Standardized } \\
\text { Coefficients }\end{array}$} & \multirow[t]{2}{*}{ t hitung } & \multirow[t]{2}{*}{$\begin{array}{l}\text { Sig. } \\
\text { uji t }\end{array}$} \\
\hline & B & Std. Error & & & \\
\hline (Constant) & 0,363 & 1,520 & & 0,239 & 0,812 \\
\hline Prestasi kerja $\left(\mathrm{X}_{1}\right)$ & 0,249 & 0,062 & 0,34 & 4,021 & 0,000 \\
\hline Senioritas $\left(\mathrm{X}_{2}\right)$ & 1,358 & 0,323 & 0,31 & 4,198 & 0,000 \\
\hline Loyalitas $\left(\mathrm{X}_{3}\right)$ & 0,363 & 1,520 & & 0,239 & 0,000 \\
\hline $\mathrm{R}^{2}$ & 0,779 & & & & \\
\hline Adjusted $\mathrm{R}^{2}$ & 0,770 & & & & \\
\hline F Statistik & 88,081 & & & & \\
\hline Signifikansi Uji F & 0,000 & & & & \\
\hline
\end{tabular}

Berdasarkan hasil analisis regresi linier berganda seperti yang disajikan pada Tabel 4, maka dapat dibuat persamaan regresi sebagai berikut:

$\mathrm{Y}=0,363+0,249 \mathrm{X}_{1}+1,358 \mathrm{X}_{2}+0,363 \mathrm{X}_{3}$

Tabel 4. menunjukkan koefisien regresi pada masing-masing variabel bebas yang diuji memiliki arah koefisien yang positif dan memiliki nilai signifikansi kurang dari 0,05. Hal ini menunjukkan bahwa seluruh variabel bebas dalam penelitian ini memiliki pengaruh yang positif dan signifikan pada variabel promosi jabatan. Model regresi akan lebih tepat digunakan dan menghasilkan perhitungan yang lebih akurat, apabila beberapa asumsi berikut dapat terpenuhi. Uji asumsi klasik yang harus dipenuhi pada analisis regresi linear berganda antara lain uji normalitas, uji multikolenearitas dan uji heterokedastisitas.

Dalam penelitian ini uji normalitas dilakukan dengan menguji normalitas residual dengan menggunakan uji Kolmogorov-Smirnov. Jika probabilitas signifikansi nilai residual lebih besar dari 0,05 maka data tersebut dikatakan berdistribusi normal. 
Tabel 5.

Hasil Uji Normalitas

\begin{tabular}{ccc}
\hline & & Unstandardized Residual \\
\hline Normal Parameters ${ }^{a, b}$ & Mean & 79 \\
Most Extreme Differences & Std. Deviation & 0,0000000 \\
& Absolute & 2,31696115 \\
& Positive & 0,084 \\
Kolmogorov-Smirnov Z & Negative & 0,038 \\
Asymp. Sig. (2-tailed) & & $-0,084$ \\
Sumber: Data diolah, 2019 & 0,749 \\
\end{tabular}

Berdasarkan hasil analisis pada Tabel 5. didapat nilai signifikansi sebesar 0,628 yang lebih dari 0,05 maka dapat disimpulkan bahwa model persamaan regresi dalam penelitian ini sudah berdistribusi normal. Uji multikoleniaritas bertujuan untuk menguji apakah dalam satu model regresi ditemukan adanya korelasi antar variabel bebas.

Model regresi yang baik adalah tidak terjadi korelasi diantara variabel bebas. Untuk mendeteksi ada atau tidaknya korelasi antar variabel bebas dapat dilihat dari nilai tolerance dan nilai variance inflation factor $(V I F)$. Jika nilai tolerance lebih dari 10\% atau VIF Kurang dari 10, maka dapat dikatakan model telah bebas dari multikolinearitas.

Berdasarkan Tabel 6. dapat dilihat bahwa nilai tolerance dan VIF dari seluruh variabel bebas yang diuji yaitu prestasi kerja, senioritas, dan loyalitas menunjukkan bahwa nilai tolerance untuk setiap variabel lebih besar dari $10 \%$ dan nilai VIF lebih kecil dari 10 yang berarti model persamaan regresi bebas dari multikolinearitas.

Tabel 6.

Hasil Uji Multikoleniaritas

\begin{tabular}{cccc}
\hline Variabel & Tolerance & VIF & Keterangan \\
\hline Prestasi kerja $\left(\mathrm{X}_{1}\right)$ & 0,391 & 2,555 & Bebas multikol \\
Senioritas $\left(\mathrm{X}_{2}\right)$ & 0,514 & 1,945 & Bebas multikol \\
Loyalitas $\left(\mathrm{X}_{3}\right)$ & 0,399 & 2,508 & Bebas multikol \\
\hline
\end{tabular}

Sumber: Data primer diolah, 2019

Uji heteroskedastisitas ini bertujuan untuk mengetahui apakah dalam model regresi terjadi ketidaksamaan varians dari residual satu pengamatan ke pengamatan lain yang dilakukan dengan uji Glejser. Model regresi yang baik adalah yang tidak mengandung gejala heteroskedastisitas atau mempunyai varians yang homogen. Jika variabel bebas yang diteliti tidak mempunyai pengaruh signifikan atau nilai signifikansinya lebih dari 0,05 terhadap nilai absolute residual, berarti model regresi tidak mengandung gejala heteroskedastisitas.

Pada Tabel 7. dapat dilihat bahwa nilai Signifikansi dari variabel prestasi kerja sebesar 0,149, nilai signifikansi variabel senioritas sebesar 0,313, dan loyalitas sebesar 0,051. Nilai tersebut lebih besar dari 0,05 yang berarti tidak terdapat pengaruh antara variabel bebas terhadap absolute residual. Dengan demikian, model yang dibuat tidak mengandung gejala heteroskedastisitas. 
Tabel 7.

Hasil Uji Heteroskedastisitas

\begin{tabular}{|c|c|c|c|c|c|}
\hline \multirow[t]{2}{*}{ Model } & \multicolumn{2}{|c|}{$\begin{array}{c}\text { Unstandardized } \\
\text { Coefficients }\end{array}$} & \multirow{2}{*}{$\begin{array}{c}\begin{array}{c}\text { Standardized } \\
\text { Coefficients }\end{array} \\
\text { Beta } \\
\end{array}$} & \multirow[b]{2}{*}{$\mathbf{t}$} & \multirow[b]{2}{*}{ Sig. } \\
\hline & B & Std. Error & & & \\
\hline (Constant) & 1,713 & 0,927 & & 1,847 & 0,069 \\
\hline Prestasi kerja & $-0,055$ & 0,038 & $-0,261$ & $-1,458$ & 0,149 \\
\hline Senioritas & $-0,201$ & 0,197 & $-0,159$ & $-1,017$ & 0,313 \\
\hline Loyalitas & 0,150 & 0,075 & 0,351 & 1,984 & 0,051 \\
\hline
\end{tabular}

Sumber: Data diolah, 2019

Berdasarkan uraian pada hasil uji normalitas, hasil uji multikoleniaritas dan hasil uji heteroskedastisitas di atas, menunjukkan bahwa semua uji asumsi klasik tersebut sudah terpenuhi sehingga hasil analisis regresi layak untuk dibahas lebih lanjut. Maka yang selanjutnya adalah menguji hasil kelayakan model.

Besarnya pengaruh variabel bebas terhadap variabel terikat ditunjukkan oleh nilai determinasi total ( $R$ Square). Hasil uji koefisien determinasi pada Tabel 4 menunjukkan nilai $\mathrm{R}$ Square sebesar 0,779 mempunyai arti bahwa sebesar 77,9\% variasi promosi jabatan pada The Royal Pita Maha dipengaruhi oleh variasi prestasi kerja, senioritas, dan loyalitas, sedangkan sisanya sebesar $22,1 \%$ dijelaskan oleh faktor lain yang tidak dimasukkan ke dalam model.

Tabel 8.

Hasil Uji Kelayakan Model (Uji F)

\begin{tabular}{ccccccc}
\hline & Model & Sum of Squares & df & Mean Square & F & Sig. \\
\hline \multirow{2}{*}{1} & Regression & 1475,272 & 3 & 491,757 & 88,081 & $0,000^{\text {a }}$ \\
& Residual & 418,728 & 75 & 5,583 & & \\
& Total & 1894,000 & 78 & & & \\
\hline
\end{tabular}

Sumber: Data diolah, 2019

Uji kelayakan model regresi bertujuan untuk mengetahui apakah semua variabel bebas yang diidentifikasi (prestasi kerja, senioritas, dan loyalitas) tepat digunakan memprediksi promosi jabatan. Uji ini sering juga disebut dengan uji F. Tingkat kepercayaan yang digunakan dalam uji ini adalah 5 persen, $\alpha=0,05$. Kriteria pengujian yaitu jika nilai $F_{\text {hitung }}>F_{\text {tabel }}$ dengan signifikansi uji $F<0,05$ maka Ho ditolak dan $\mathrm{H}_{1}$ diterima, begitu pula sebaliknya.

Hasil pengolahan data pada Tabel 8 dengan menggunakan program SPSS

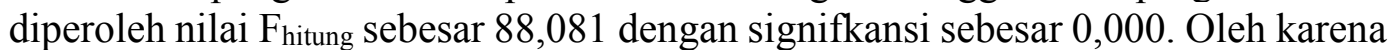

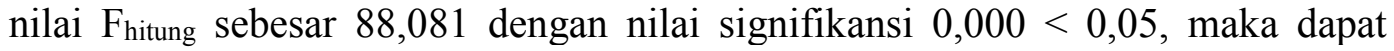
disimpulkan bahwa pada kelompok yang diuji memiliki perbedaan yang nyata (signifikan). Hasil ini mempunyai arti bahwa secara simultan prestasi kerja, senioritas, dan loyalitas berpengaruh signifikan terhadap promosi jabatan The Royal Pita Maha.

Pengaruh secara parsial pada variabel prestasi kerja, senioritas, dan loyalitas terhadap promosi jabatan diuji dengan menggunakan uji regresi linier berganda yang ditinjau berdasarkan nilai thitung pada tabel 4 (coefficient). Kriteria pengujian untuk menjelaskan interpretasi pengaruh antar masing-masing variabel yakni apabila nilai signifikansi $<0,05$ maka $\mathrm{H}_{0}$ ditolak dan $\mathrm{H}_{1}$ diterima. Sebaliknya, jika 
nilai signifikansi $>0,05$ maka $\mathrm{H}_{0}$ diterima dan $\mathrm{H}_{1}$ ditolak. Adapun hasil uji hipotesis dalam penelitian ini yaitu:

Berdasarkan hasil analisis pengaruh prestasi kerja terhadap promosi jabatan diperoleh nilai signifikansi sebesar 0,000 dengan koefisien regresi yang positif sebesar 0,249. Nilai Signifikansi 0,000<0,050, maka mengindikasikan bahwa $\mathrm{H}_{0}$ ditolak dan $\mathrm{H}_{1}$ diterima. Hasil ini mempunyai arti bahwa Senioritas berpengaruh positif dan signifikan terhadap promosi jabatan pada The Royal Pita Maha.

Berdasarkan hasil analisis pengaruh senioritas terhadap promosi jabatan diperoleh nilai signifikansi sebesar 0,000 dengan nilai koefisien regresi yang positif sebesar 1,358. Nilai Signifikansi $0,000<0,050$, maka mengindikasikan bahwa $\mathrm{H}_{0}$ ditolak dan $\mathrm{H}_{2}$ diterima. Hasil ini mempunyai arti bahwa Senioritas berpengaruh positif dan signifikan terhadap promosi jabatan pada The Royal Pita Maha.

Berdasarkan hasil analisis pengaruh loyalitas terhadap promosi jabatan diperoleh nilai signifikansi sebesar 0,000 dengan nilai koefisien regresi positif sebesar 0,469. Nilai signifikansi $0,000<0,05$ mengindikasikan bahwa $\mathrm{H}_{0}$ ditolak dan $\mathrm{H}_{3}$ diterima. Hasil ini mempunyai arti bahwa loyalitas berpengaruh positif dan signifikan terhadap promosi jabatan pada The Royal Pita Maha.

Berdasarkan hasil analisis data diketahui bahwa prestasi kerja berpengaruh positif dan signifikan terhadap promosi jabatan. Hal ini mengandung arti bahwa semakin baik prestasi kerja seorang karyawan dalam melaksanakan pekerjaan berakibat pada semakin baik promosi jabatan yang akan di dapatkan di The Royal Pita Maha. Prestasi kerja yang baik menunjukkan sumber daya yang kompeten terhadap perusahaan. Hasil penelitian ini mendukung pernyataan. Mandiangan \& Rahayuda (2015) mengatakan bahwa prestasi kerja berpengaruh positif dan signifikan terhadap promosi jabatan.

Hasil analisis data senioritas berpengaruh positif dan signifikan terhadap promosi jabatan. Ini berarti bahwa semakin senior seseorang maka semakin besar peluang memperoleh promosi jabatan di The Royal Pita Maha. Hasil penelitian ini mendukung pernyataan (Hamzah dkk., 2013) yang menyatakan bahwa di lapangan tingkat senioritas berpengaruh positif dan dominan terhadap promosi jabatan. Donald \& Jeffrey (2003) menyebutkan bahwa tingkat senioritas menentukan promosi jabatan dan dapat membantu untuk menghindari diskriminasi.

Hasil analisis data loyalitas berpengaruh positif dan signifikan terhadap promosi jabatan. Ini berarti bahwa adanya loyalitas kerja karyawan yang baik maka akan meningkatkan peluang memperoleh promosi jabatan di The Royal Pita Maha. Upaya dari memelihara sumber daya manusia yang baik akan menciptakan loyalitas kerja karyawan yang berarti kesetiaan untuk tidak keluar dari perusahaan dan berakhir pada promosi jabatan yang diperoleh oleh seseorang karyawan sebagai bentuk pemeliharaan dari sumber daya manusia, pengaruh loyalitas kerja akan kembali sebagaimana karyawan dapat mengembangkan prestasinya (Mandiangan \& Rahayuda, 2015).

Hasil penelitian ini searah dengan pernyataan Andhara dkk. (2015) mengatakan bahwa loyalitas kerja berpengaruh parsial signifikan terhadap promosi jabatan. Loyalitas kerja mempunyai pengaruh dalam penentuan proses promosi jabatan yang ada di perusahaan. Selain itu dalam penelitiannya Hamzah dkk. (2013) 
mengatakan bahwa senioritas karyawan dan loyalitas kerja karyawan secara parsial berpengaruh signifikan terhadap promosi jabatan.

Hasil penelitian menunjukkan bahwa prestasi kerja, senioritas dan loyalitas karyawan memberikan pengaruh yang positif dan signifikan terhadap promosi jabatan. Implikasi dari hasil penelitian yang didapat diharapkan mampu menjadikan tambahan pengetahuan, referensi dan bahan pertimbangan bagi pihak manajemen The Royal Pita Maha dalam proses pengambilan keputusan dan penetapan kebijakan untuk mempromosikan karyawan.

Selain itu, prestasi kerja, senioritas dan loyalitas karyawan juga menjadi faktor yang sangat menentukan promosi jabatan, oleh sebab itu manajemen sebaiknya manilai karyawan tidak berdasarkan satu kreteria saja, namun sebaiknya berdasarkan prestasi kerja, senioritas dan loyalitas karyawan, sehingga karyawan merasa lebih adil dan lebih termotivasi untuk mendapatkan promosi jabatan yang lebih tinggi. Jika kebijakan promosi mampu diterapkan dan dijalankan dengan baik dan adil, maka akan memberikan dampak yang baik pula pada kinerja karyawan pada The Royal Pita Maha.

Adapun keterbatasan dalam penelitian ini yaitu Penelitian ini hanya meneliti tentang beberapa variabel prestasi kerja, seioritas dan loyalitas kerja, kedepannya agar dikembangkan dengan memilih lainnya seperti disiplin kerja, kepemimpinan, motivasi kerja, dan faktor situasional yang dapat mempengaruhi keputusan promosi jabatan. Penelitian ini hanya meneliti jumlah sampel dan ruang lingkup yang terbatas. Kedepannya agar menambahkan jumlah sampel dan memperluas ruang lingkup penelitian tidak hanya terbatas di The Royal Pita Maha. Sampel diambil dalam satu waktu tertentu (cross section) sedangkan lingkungan cepat berubah, sehingga penelitian ini penting dilakukan di masyarakat lainnya dengan menambahkan indikator pengaruh lainnya.

\section{SIMPULAN}

Prestasi kerja berpengaruh positif dan signifikan terhadap promosi jabatan. Hal ini memiliki makna bahwa semakin baik prestasi kerja karyawan, maka akan semakin baik pula promosi jabatan pada The Royal Pita Maha. Senioritas berpengaruh positif dan signifikan terhadap promosi jabatan. Hal ini memiliki makna bahwa semakin senior karyawan, maka semakin baik pula promosi jabatan pada The Royal Pita Maha. Loyalitas kerja berpengaruh positif dan signifikan terhadap promosi jabatan. Hal ini memiliki makna bahwa semakin baik loyalitas kerja karyawan, maka semakin baik pula promosi jabatan pada The Royal Pita Maha.

Pihak manajemen The Royal Pita Maha sebaiknya lebih meningkatkan kreativitas karyawan dengan memberikan kepercayaan pada karyawannya untuk memberikan ide-ide baru atau masukan untuk kemajuan dan perkembangan perusahaan, agar karyawan merasa dihargai dan dianggap sebagai bagian dari perusahaan. Pihak manajemen juga sebaiknya mempertahankan kebijakan yang menyangkut variabel prestasi kerja seperti kulitas maupun kuantitas, kedisiplinan, kerja sama, kepribadian, prakarsa dan tanggung jawab yang sesuai pedoman dalam 
promosi jabatan. Sehingga promosi jabatan pada The Royal Pita Maha akan semakin baik.

Pihak manajemen The Royal Pita Maha sebaiknya lebih mempertimbangkan kebijakan masa kerja karyawan dalam menentukan promosi jabatan, untuk mencegah keluarnya karyawan yang sudah lama bekerja dan sudah loyal kepada perusahaan. Sehingga promosi jabatan pada The Royal Pita Maha akan semakin baik. Pihak manajemen The Royal Pita Maha sebaiknya memberikan pelatihan dan pendidikan pada seluruh karyawan agar mampu menerima dan menghadapi resiko saat bekerja dengan cara memberikan pelatihan yang sesuai dengan bidangnya, agar karyawan betul-betul memahami pekerjaan mereka, sehingga karyawan memiliki mental yang baik dan siap menerima resiko saat bekerja dan mampu untuk memecahkan masalah pekerjaan. Pihak manajemen juga sebaiknya mempertahankan kebijakan yang menyangkut variabel loyalitas kerja seperti taat pada peraturan, tanggung jawab dan sikap kerja yang sesuai pedoman dalam promosi jabatan. Sehingga promosi jabatan pada The Royal Pita Maha akan semakin baik. Pihak manajemen The Royal Pita Maha sebaiknya lebih mempertimbangkan latar belakang pendidikan karyawan dalam promosi jabatan dan tidak melakukan penilaian berdasarkan faktor kedekatan dan lebih memproritaskan pegawai asli Ubud atau pegawai asli Bali untuk di promosikan, karena hal tersebut akan menimbulkan ketidak adilan dan tidak adanya faktor nepotisme dalam promosi jabatan. Jadi pihak manajemen The Royal Pita Maha sebaiknya memperbaiki dan lebih selektif untuk memilih kandidat untuk di promosikan. Dengan demikian promosi jabatan pada The Royal Pita Maha semakin baik.

\section{REFERENSI}

Adedeji, A. O., \& Ugwumadu, O. C. (2018). Factors Motivating Employee Loyalty and Employee Retention in Deposit Money Banks in Nigeria. International Journal of Human Resource Studies, 8(3), 300. https://doi.org/10.5296/ijhrs.v8i3.13555

Andhara, S. De, Utami, H. N., \& Mayowan, Y. (2015). Pengaruh Senioritas Dan Loyalitas Terhadap Promosi Jabatan ( Studi pada Karyawan Departemen Kebijakan Ekonomi dan Moneter Bank Indonesia Jakarta ). Jurnal Administrasi Bisnis (JAB), 22(1), 1-9.

Ardana, Mujiati, \& Utama, M. (2012). Manajemen Sumber Daya Manusia. Yogyakarta: Graha Ilmu.

Arifin, T., \& Mutamimah. (2009). Model Peningkatan Loyalitas Dosen Melalui Kepuasan Kerja Dosen. Jurnal Siasat Bisnis, 13(2), 185-201.

Barusman, M. Y. S., \& Siswadi. (2018). Employee Interest in Following Promotion Selection through Open Bidding. Review of Integrative Business and Economics Research, 7(1), 322-329.

Breaugh, J. A. (2011). Modeling The Managerial Promotion Process. Journal of 
Managerial Psychology, 26(4), 264-277. https://doi.org/10.1108/02683941111124818

Busari, A. H., Mughal, Y. H., Khan, S. N., Rasool, S., \& Kiyan, A. A. (2017). Analytical Cognitive Style Moderation On Promotion And Turnover Intention. Journal of Management Development, 36(3), 1-12.

Busswolder, P., Dregert, S., \& Letmathe, P. (2019). Consequences of Unfair Job Promotions in Organizations. Schmalenbach Business Review, 71(1), 27-33. https://doi.org/10.1007/s41464-019-00071-0

Carter, M. E. (2017). Seniority and Transparency in the Perceived Fairness of Seniority-Based Police Promotion. Walden University.

Chen, Y.-C., Chen, H.-I., Tsui, P.-L., \& Chiang, Y.-C. (2016). Contributing causes of employee loyalty of service personnel in international hotels. International Journal of Organizational Innovation, 9(1), 107-118.

Cressida, F., Musadieq, A.-, \& Hakam, S. (2013). Pengaruh Prestasi Kerja Karyawan Terhadap Promosi Jabatan (Studi Pada Karyawan Bank Sumsel babel Cabang Kapten A. Rivai Palembang). Jurnal Administrasi Bisnis, 3(1), $1-8$.

Dasplin. (2014). Analisis Pengaruh Mutasi, Dan Promosi Jabatan Terhadap Pengembangan Karir Pegawai Di Manado. Jurnal Riset Bisnis Dan Manajeme Universitas Sam Ratulangi, 2(3), 15-24.

Desmita, L., \& Kasmiruddin. (2018). Pengaruh Senioritas Dan Loyalitas Terhadap Promosi Jabatan Pada Karyawan Dealer Mobiltoyota (Studi Pada PT. Agung Automall Cabang Sutomo Pekanbaru). JOM FISIP, 5(1), 1-14.

Donald, D., \& Jeffrey, E. (2003). Seniority systems and the ADA. Employee Benefit Plan Riview, 57(9), 32-33.

George, Olusoji ; Bamigbola, B. O. ; (2016). Effect of reward and compensation on employee loyalty and performance in asset management corporation of Nigerian. International Journal of Management and Development Studies, 2(49-60), 49-60.

Hamzah, M. ., Musadieq, M. ., \& Hakam, M. . (2013). Pengaruh Senioritas dan Loyalitas Terhadap Promosi Jabatan (Studi Pada Karyawan PT. Pembangunan Perumahan DVO III Surabaya). Jurnal Administrasi Bisnis (JAB), 2(2), 1-10.

Harmania, H. M. ., \& Nessa, H. C. . (2017). Exploring the Effect of Staff Achievement on Job Satisfaction in Hong Kong Residential Clubhouse. Journal of Tourism \& Hospitality, 05(06), 1-8. https://doi.org/10.4172/21670269.1000259

Hasibuan, M. S. . (2013). Manajemen Sumber Daya Manusia. Jakarta: PT. Bumi Aksara. 
Horak, S., \& Yang, I. (2017). Whither seniority? Career progression and performance orientation in South Korea. International Journal of Human Resource Management, 5192(August), 1-29. https://doi.org/10.1080/09585192.2017.1362659

Ismawan, A. (2006). Studi Korelasi Prestasi Kerja Dan Loyalitas Kerja Dengan Promosi Jabatan Pada Karyawan PT. Pabelan Surakarta Tahun 2006 (Vol. 33). Universitas Sebelas Maret.

Kwon, I., \& Meyersson Milgrom, E. M. (2014). The Significance Of firm And Occupation Specific Human Capital For Hiring And Promotions. Labour Economics, 31(3), 162-173. https://doi.org/10.1016/j.labeco.2014.07.003

Mandiangan, E. ., \& Rahayuda, A. . (2015). Pengaruh Prestasi Kerja, Senioritas, Dan Loyalitas Terhadap Promosi Jabatan Pada Discovery Kartika Plaza Hotel Bali. E-Jurnal Manajemen Unud, 4(5), 1386-1405.

Mangkunegara, A. A. A. . (2011). Manajemen Sumber Daya Manusia Perusahaan. Bandung: PT. Remaja Rosdakarya.

Matias, A., \& Bentor, J. (2016). Job Promotion Practices and its Associated Problems: The Case of Non-Teaching Staff in an Academic Environment. International Journal of Sciences: Basic and Applied Research (IJSBAR), 28(3), 107-117.

Mirayanti. (2015). Pengaruh Loyalitas, Pendidikan Dan Pelatihan Serta Kinerja Terhadap Promosi Jabatan Pada Kantor Sekretariat Daerah Kabupaten Tolitoli. E-Jurnal Katalogis, 3(1), 95-104.

Ningsih, F. . (2013). Pengaruh Efektivitas Komunikasi Interpersonal Terhadap Promosi Jabatan pada Dinas Sosial Daerah Provinsi Sulawesi Tengah. Jurnal Komunikasi KAREBA, 2(4), 295-304.

Nitisemito, A. . (2008). Manajemen Personalia. Jakarta: Adisi Indonesia.

Prabowo, B., Al Musadieq, M., \& Ruhana, I. (2016). Pengaruh Promosi Jabatan Terhadap Motivasi Kerja Dan Prestasi Kerja (Studi Pada Karyawan Pt Telkom Indonesia Witel Jatim Selatan Malang). Jurnal Administrasi Bisnis (JAB), 32(1), 106-113.

Pratimi, D. M., \& Utama, I. W. M. (2016). Pengaruh Loyalitas Dan Prestasi Kerja Terhadap Promosi Jabatan Pada The Jayakarta Bali Hotel. E-Jurnal Manajemen Unud, 5(11), 7446-7472.

Purwaningsih, A., \& Magdalena, B. (2017). Pengaruh Senioritas dan Prestasi Kerja terhadap Promosi Jabatan pada Karyawan. Jurnal Bisnis Darmajaya, 3(1), 14-26.

Rasimin, B. S. (2008). Manusia dalam Industri dan Organisasi. Yogyakarta: Universitas Gadjah Mada.

Razak, A., Sarpan, S., \& Ramlan, R. (2018). Influence of Promotion and Job 
Satisfaction on Employee Performance. Journal of Accounting, Business and Finance Research, 3(1), 18-27. https://doi.org/10.20448/2002.31.18.27

Rinaldi, U., Sani, S., \& Martono, M. (2018). Mutation and Promotion System and Its Relation To Employeesatisfaction and Job Performance of West Kalimantan Immigration Office. Jurnal Aplikasi Manajemen, 16(1), 106114. https://doi.org/10.21776/ub.jam.2018.016.01.13

Roswaty, F. I., \& Kurniawan, M. (2016). Tinjauan Penilaian Kinerja Karyawan Sebagai Dasar Promosi Jabatan Pada PT. Kereta Api Indonesia (Persero) Divisi Regional III Sumatera Selatan. Jurnal Ilmiah Ekonomi Global Masa Kini, 7(03), 8-15.

Saharuddin, \& Sulaiman. (2016). The Effect Of Promotion And Compensation Toward Working Productivity Through Job Satisfaction And Working Motivation Of Employees In The Department Of Water And Mineral Resources Energy North Aceh District. International Journal of Business and Management Invention ISSN (Online, 5(10), 33-40. Retrieved from www.ijbmi.org

Sarboni. (2016). Performance Of Employees And Impact On Promotion Of Position. Jurnal Ilmiah Peuradeun, 4(1), 103-114.

Sari, E. N., \& Daulay, I. . (2015). Pengaruh Kepuasan Kerja, Komitmen Dan Promosi Jabatan Terhadap Turnover Intention Pada Karyawan PT. Orindo Alam Ayu Cabang Pekanbaru. JOM FEKON, 2(1), 1-15.

Sasmita, I. A. G. D., \& Mujiati, N. W. (2016). Pengaruh Prestasi Kerja Dan Kompetensi Karyawan Terhadap Promosi Jabatan Pada Inna Sindhu Beach Hotel Sanur,Denpasar. E-Jurnal Manajemen Unud, 5(8), 4807-4834.

Siagian, S. P. (2014). Manajemen Sumber Daya Manusia. Jakarta: PT Bumi Aksara.

Sihombing, S. O., \& Berlianto, M. P. (2017). Antecedents of Customer Loyalty in an e-commerce Setting: An Empirical Study. International Research Journal of Business Studies, 10(2), 99-109.

Sinaga, S. (2014). Sistem Promosi Jabatan Pada PT. PLN (Persero) Wilayah Sumatera Utara. Jurnal Ilman, 1(1), 36-46.

Siska, A. ., \& Suryalena. (2017). Pengaruh Prestasi Kerja Dan Loyalitas Terhadap Promosi Jabatan (Studi Pada Karyawan Bagian Sales Executive and Counter Pada PT. Agung Automall Cabang Pekanbaru). JOM FISIP, 4(2), 1-14.

Stephani, L. ., \& Wibawa, I. M. . (2014). Pengaruh Kompensasi dan Lingkungan Kerja Pada Loyalitas kerja Karyawan Berdasarkan Jenis Kelamin. Jurnal Manajemen Dan Bisnis, 3(10), 3078-3095.

Suswanto, D. . (2016). Manajemen SDM dalam Organisasi Publik dan Bisnis. Bandung: Alfabeta. 
Tomic, I., Tesic, Z., Kuzmanovic, B., \& Tomic, M. (2018). An Empirical Study Of Employee Loyalty, Service Quality, Cost Reduction And Company Performance. Economic Research-Ekonomska Istrazivanja, 31(1), 827-846. https://doi.org/10.1080/1331677X.2018.1456346

Waqas, A., Bashir, U., Sattar, M. ., Abdullah, H., Mussain, I., \& Anjum, W. (2014). Factors Influencing Job Satisfaction and Its Impact on Job Loyalty. International Journal Of Learning \& Development, 4(2), 141-161. 